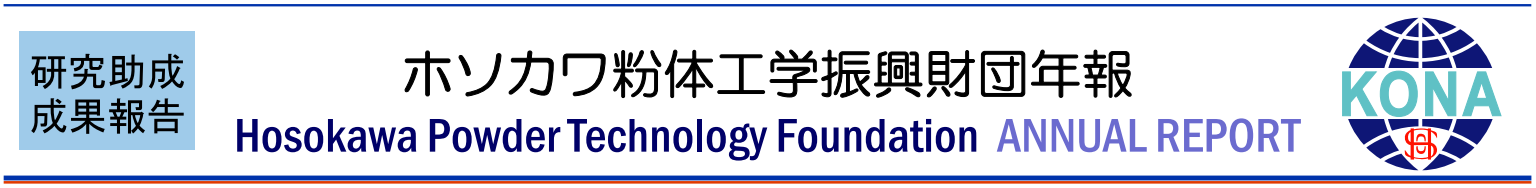

16103

\title{
アニオン包接結晶をコアに持つアパタイトナノ結晶の開発 \\ Fabrication of Apatite Nanocrystals on the Surface of C12A7 Crystal
}

研究代表者 Research leader：稲田幹 Miki INADA

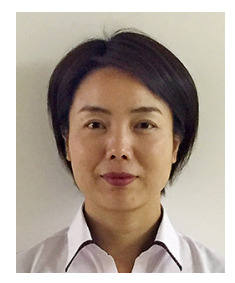

九州大学中央分析センター 准教授

Center of Advanced Instrumental Analysis, Kyushu University, Associate Professor

E-mail: inada.miki.300@m.kyushu-u.ac.jp

抄 録

本研究は,アニオンを包接した $12 \mathrm{CaO} \cdot 7 \mathrm{Al}_{2} \mathrm{O}_{3}(\mathrm{C} 12 \mathrm{~A} 7)$ 多孔体表面をアパタイト結晶で被覆した 新規コアーシェル結晶を開発することを目的に行った。計画では，(1) C12A7ナノ結晶を合成し， (2)表面をアパタイト化してコアーシェル結晶を作製し, (3)擬似体液浸漬法により生体親和性の評価 を行う予定であったが，(1) C12A7 多孔質ナノ結晶の開発についてのみ達成できた，C12A7 前駆体 であるハイドロガーネットを合成するため, $\mathrm{Ca}(\mathrm{OH})_{2}$ ゾルと $\mathrm{Al}(\mathrm{OH})_{3}$ ゾルを混合・熟成した。得ら れたハイドロガーネットの熱処理により水酸基の脱離に伴う多孔質化とともに C12A7 の結晶化が 起こり， $50 \mathrm{~m}^{2} / \mathrm{g}$ を超える比表面積を有する高結晶な多孔質 $\mathrm{C} 12 \mathrm{~A} 7$ 粒子の開発に成功した。これま でのどの報告よりも高い比表面積を達成でき，本研究の目的に沿った結果であった。

\begin{abstract}
$12 \mathrm{CaO} \cdot 7 \mathrm{Al}_{2} \mathrm{O}_{3}(\mathrm{C} 12 \mathrm{~A} 7)$ is composed of cationic cages in which various anions are incorporated. Conventionally, most of reported $\mathrm{C} 12 \mathrm{~A} 7$ were synthesized by solid state reaction at high temperature above $1200^{\circ} \mathrm{C}$ using starting reagents such as $\mathrm{CaCO}_{3}$ and $\gamma-\mathrm{Al}_{2} \mathrm{O}_{3}$. This strict heating condition causes the undesirable problems such as increase of the $\mathrm{C} 12 \mathrm{~A} 7$ particle size and decrease of specific surface area (SSA). Liquid phase process is one of the potential methods of synthesis of C12A7 fine particles with high SSA, which does not require high temperature for heat treatment. In this study, $\mathrm{C} 12 \mathrm{~A} 7$ porous particles were synthesized from $3 \mathrm{CaO} \cdot \mathrm{Al}_{2} \mathrm{O}_{3} \cdot 6 \mathrm{H}_{2} \mathrm{O}$ (hydrogarnet) as precursor prepared by liquid phase process. The synthesized $\mathrm{C} 12 \mathrm{~A} 7$ were cubic-shaped particles with porous surfaces and the SSA reached the maximum at $55 \mathrm{~m}^{2} / \mathrm{g}$.
\end{abstract}

研究背景と目的

$$
\text { マイエナイト } 12 \mathrm{CaO} \cdot 7 \mathrm{Al}_{2} \mathrm{O}_{3} \text { ( 以下 } \mathrm{C} 12 \mathrm{~A} 7 \text { ) }
$$

結晶は正電荷を帯びたケージ構造内に種々の陰 イオン $\left(\mathrm{F}^{-}, \mathrm{Cl}^{-}, \mathrm{OH}^{-}, \mathrm{O}^{2-}, \mathrm{O}_{2}^{-}, \mathrm{O}^{-}, \mathrm{S}^{2-}, \mathrm{H}^{-}\right.$
など）を包接する結晶である（図 1)。アニオ

ン置換された C12A7 は化学量論組成の C12A7 とは，大きく異なる特性を示し，さまざまな分 野で応用が期待されている。特に $\mathrm{e}^{-}$を包接し たC12A7 エレクトライドは, 電子放出素子や 


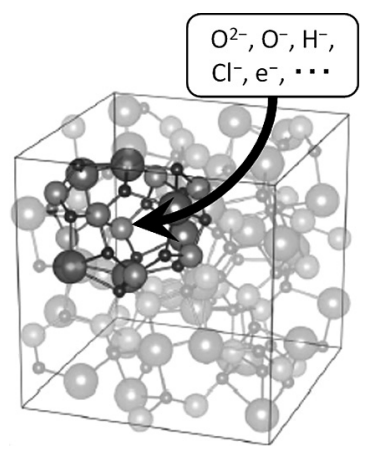

Fig. 1 Unit cell of C12A7 crystal. Spheres indicate Ca, $\mathrm{Al}$ and $\mathrm{O}$ elements in descending order.

還元触媒としての利用が期待されており, 高比 表面積化が望まれている。C12A7 は従来，固 相法により $1200^{\circ} \mathrm{C}$ 以上の高温で合成されてお り, 得られる $12 \mathrm{~A} 7$ は粗粒で比表面積が低い ( 数 $\left.\mathrm{m}^{2} / \mathrm{g}\right)$. 粉体を得るには粉砕が必要であ り，表面に欠陥が導入されるため特性の低下を 生じる問題がある.

C12A7 の Caサイトを全て Sr に置換した物 質 $12 \mathrm{SrO} \cdot 7 \mathrm{Al}_{2} \mathrm{O}_{3}$ （以下 $\mathrm{S} 12 \mathrm{~A} 7$ ） は, $\mathrm{C} 12 \mathrm{~A} 7$ と ほぼ同様の結晶構造を持つが, $\mathrm{SrO}-\mathrm{Al}_{2} \mathrm{O}_{3}$ 系の 準安定相であることから C12A7 に比べて合成 が難しいとされていた. Hayashi らはS12A7 固 相合成において温度変化に伴った主相変化を調 査し， $3 \mathrm{SrO} \cdot \mathrm{Al}_{2} \mathrm{O}_{3} \cdot 6 \mathrm{H}_{2} \mathrm{O} （ \mathrm{~S} 3 \mathrm{AH} 6, \mathrm{Sr}-$ ハイドロ ガーネット）が S12A7 前駆体であることを見 出した ${ }^{[1]}$. C12A7 系でも同様な現象が起きる と考え, 本研究では $\mathrm{C} 12 \mathrm{~A} 7$ 前駆体として $3 \mathrm{CaO} \cdot \mathrm{Al}_{2} \mathrm{O}_{3} \cdot 6 \mathrm{H}_{2} \mathrm{O} （ \mathrm{C} 3 \mathrm{AH} 6$, ハイドロガーネッ ト）を液相合成し，C12A7 の高比表面積化を 目的とした。

さらに, C12A7 表面をアパタイト結晶で被 覆させ，C12A7 が包接するアニオン種によっ て表面に析出するアパタイトシェルの組成が変 化し，コアーシェル間に静電的な分極を持たせ てアパタイトの特性向上を図ることを目的とし た。 ハイドロキシアパタイト $\mathrm{Ca}_{10}\left(\mathrm{PO}_{4}\right)_{6}(\mathrm{OH})_{2}$ に代表されるアパタイト化合物は，人工骨や歯 科材料, DNA 精製カラムに利用されている。 $\mathrm{OH}^{-}$サイトは様々のアニオンに置換でき, アニ
オン種によってアパタイトの生体親和性や吸着 特性などが変化する，アニオン包接結晶をコア にすることでアパタイトの組成変化とコア シェル分極効果による特性向上を期待したが, 本研究ではアパタイトを $\mathrm{C} 12 \mathrm{~A} 7$ 表面に合成す ることができず,本項については未達成である.

\section{研 究 方 法}

三五らにより報告された常圧水溶液法によっ て C12A7 前駆体であるハイドロガーネットを 合成した ${ }^{[2]}$. 粒径の異なる水酸化カルシウム $\mathrm{Ca}(\mathrm{OH})_{2}$ と水酸化アルミニウム $\mathrm{Al}(\mathrm{OH})_{3}$ を出発 物質として用いた。市販の $\mathrm{Ca}(\mathrm{OH})_{2}$ と $\mathrm{Al}(\mathrm{OH})_{3}$ を粗粒（Coarse）な出発原料と定義した。微粒 (Fine）原料である水酸化物ゾルは次のように 調整した。硝酸カルシウム 4 水和物と硝酸アル ミニゥム 9 水和物をモル比で $\mathrm{Ca} / \mathrm{Al}=3$ となる ように秤量し，それぞれ純水に溶解させた。 $\mathrm{Ca}-\mathrm{OH}$ 水溶液に $10 \mathrm{M}$ 水酸化ナトリウム水溶液 を, $\mathrm{Al}-\mathrm{OH}$ 水溶液に $25 \%$ アンモニア水溶液を 加え 20 分間攪拌した。 得られた $\mathrm{Ca}(\mathrm{OH})_{2}$ 沈殿 はデカンテーションにより, $\mathrm{Al}(\mathrm{OH})_{3}$ 沈殿は遠 心分離により, 分離, 洗浄した. $\mathrm{Ca}(\mathrm{OH})_{2}$ と $\mathrm{Al}(\mathrm{OH})_{3}$ を混合し, 水を加えて $100^{\circ} \mathrm{C}$ で 1-5 時 間還流後, ブフナー漏斗で吸引ろ過し, 一晚真 空乾燥した。得られた乾燥粉末を $500-900^{\circ} \mathrm{C}$ で1-6 時間焼成した後, 副生成相である $\mathrm{CaO}$ を除去するため $0.1 \mathrm{M} \mathrm{NH}_{4} \mathrm{Cl} / \mathrm{MeOH}$ 溶液で洗浄 L, C12A7 粉末を得た。得られた試料は XRD, SEM， $\mathrm{N}_{2}$ 吸脱着測定により評価した。

\section{研 究成 果}

$\mathrm{Ca}(\mathrm{OH})_{2}$ と $\mathrm{Al}(\mathrm{OH})_{3}$ の混合分散溶液を加熱 したところ，原料である $\mathrm{Ca}(\mathrm{OH})_{2}$ とともに 八イドロガーネットと $\mathrm{CaCO}_{3}$ 水和物 $\left(\mathrm{C} 3 \mathrm{~A} 2 \cdot \mathrm{CaCO}_{3} \cdot \mathrm{H} 24, \mathrm{C} 3 \mathrm{~A} \cdot \mathrm{CaCO}_{3} \cdot \mathrm{H} 11\right)$ が確認さ れた（図 2(I)）。焼成後は $\mathrm{C} 12 \mathrm{~A} 7$ と $\mathrm{CaO}$ のピー クが確認され (図 2(II)), $\mathrm{CaO}$ を $0.1 \mathrm{M} \mathrm{NH}_{4} \mathrm{Cl} /$ $\mathrm{MeOH}$ 溶液を用いて除去することで $\mathrm{C} 12 \mathrm{~A} 7$ 単 
相が得られた。原料粒子と $900^{\circ} \mathrm{C} て ゙ ~ 6$ 時間焼成 した試料の SEM 像を図 3 に示す。粗大な市販 $\mathrm{Al}(\mathrm{OH})_{3}$ を用いると不定形粒子が，微粒 $\mathrm{Al}(\mathrm{OH})_{3}$ を用いると一辺が $1-2 \mathrm{~mm}$ 程度の立方体粒子が 生成した。生成粒子の形態は, $\mathrm{Ca}(\mathrm{OH})_{2}$ 粒径と は関係なく $\mathrm{Al}(\mathrm{OH})_{3}$ 粒径のみに依存し, $\mathrm{Al}(\mathrm{OH})_{3}$ の粒径が小さい場合にハイドロガー ネットの自形である立方状粒子が生成した.

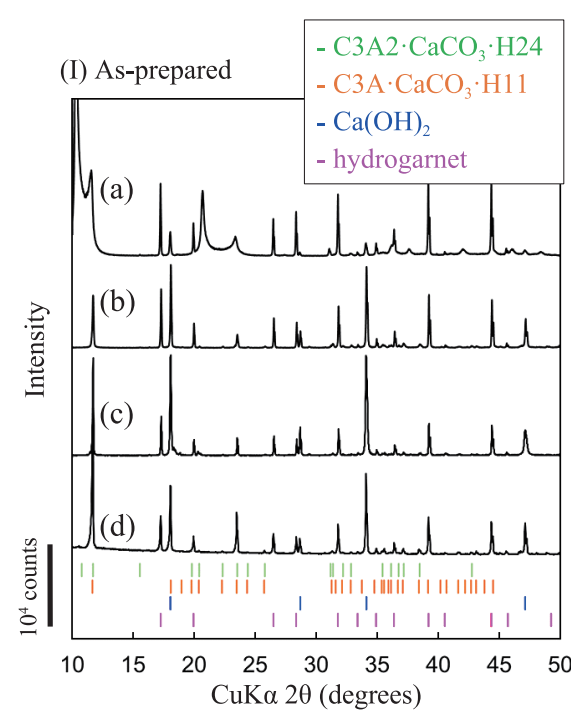

微粒 $\mathrm{Al}(\mathrm{OH})_{3}$ を用いて生成したハイドロガー ネットは平滑な表面を持つ粒子であったが，焼 成後に $\mathrm{CaO}$ を溶解除去することで表面に 100 $200 \mathrm{~nm}$ 程度の孔が生成した（図 4). 立方状多 孔体の BET 比表面積は最大で $55 \mathrm{~m}^{2} / \mathrm{g}$ を示し, 固相法で合成した C12A7 の比表面積 $\left(1 \mathrm{~m}^{2} / \mathrm{g}\right)$ と比べ,飛躍的に高かった。これらのことから， 熱処理過程で前駆体であるハイドロガーネット

Fig. 2 XRD of (I) as-prepared and (II) heat-treated samples. The samples were prepared from (a) Coarse Ca-OH and Coarse Al-OH, (b) Fine Ca-OH sol and Coarse Al-OH, (c) Coarse Ca-OH and Fine Al-OH sol, and (d) Fine Ca-OH sol and Fine Al-OH sol, respectively.

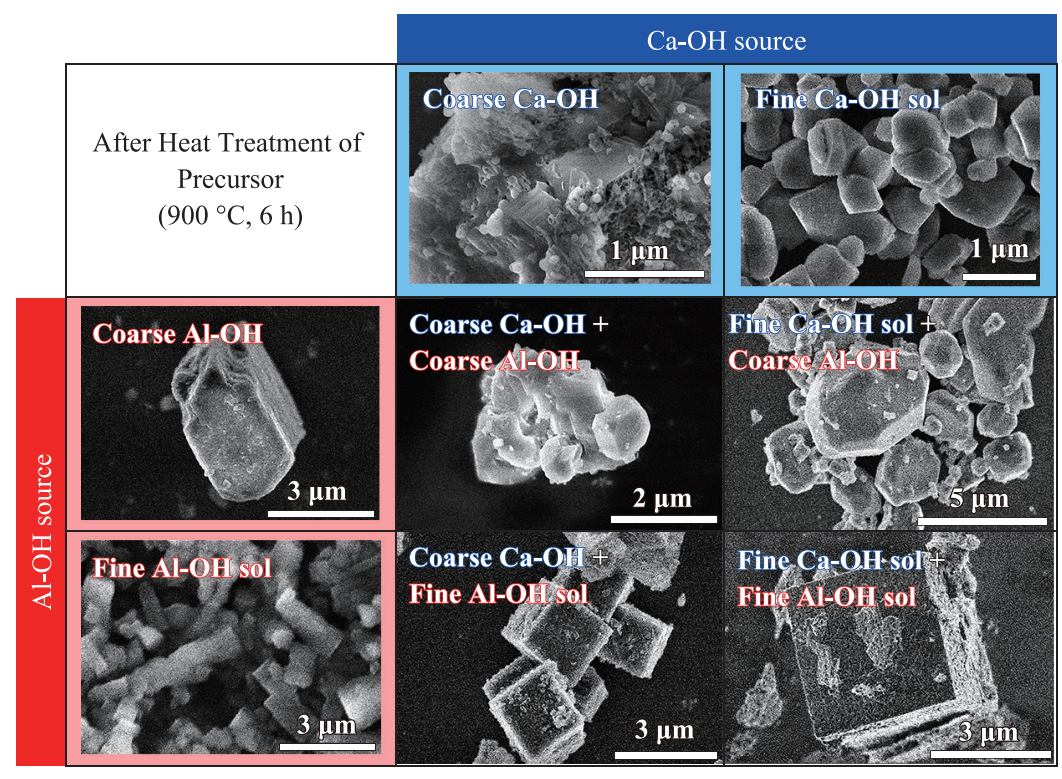

Fig. 3 SEM images of sources and heat-treated samples. 


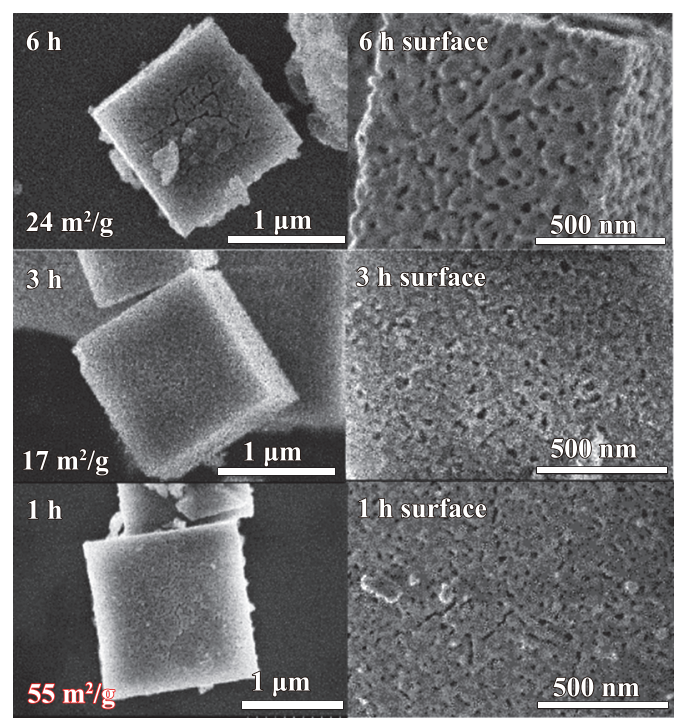

Fig. 4 SEM images of heat-treated particles after removal of $\mathrm{CaO}$.

から $\mathrm{C} 12 \mathrm{~A} 7$ と $\mathrm{CaO}$ が，不純物である $\mathrm{Ca}(\mathrm{OH})_{2}$

や $\mathrm{CaCO}_{3}$ から $\mathrm{CaO}$ が生成し, $0.1 \mathrm{M} \mathrm{NH}_{4} \mathrm{Cl} /$

$\mathrm{MeOH}$ 溶液によって $\mathrm{CaO}$ が溶解除去されるこ

外部発表成果

\section{口頭・ポスター発表}

1. 守谷 静香, 稲田 幹, 榎本 尚也, 林 克郎, “C12A7 微粒子の液相合成とエレクトライド 化”, 日本セラミックス協会 2016 年年会, 2016 年 3 月 (口頭発表).

2. 守谷 静香, 稲田 幹, 長谷川丈二, 榎本 尚也,
とで C12A7が単相として得られたこと，また， ハイドロガーネットの熱分解ではスピノーダル 分解のような現象が起きることが示唆された。

なお，得られた $\mathrm{C} 12 \mathrm{~A} 7$ 立方状多孔体をリン 酸溶液に浸漬し，表面へのアパタイト析出を試 みたが，合成条件を見出せず，アパタイト生成 には至らなかった，今後の課題としたい.

\section{参考文献}

[1] Hayashi K., Ueda N., Matsuishi S., Hirano M., Kamiya T., Hosono H., Solid state syntheses of $12 \mathrm{SrO} \cdot 7 \mathrm{Al}_{2} \mathrm{O}_{3}$ and formation of high density oxygen radical anions, $\mathrm{O}^{-}$and $\mathrm{O}_{2}$, Chemistry of Materials, 20 (2008) 59875996. DOI: 10.1021/cm800666p

[2] Sango H., Miyakawa T., Synthesis of $3 \mathrm{CaO} \cdot \mathrm{Al}_{2} \mathrm{O}_{3} \cdot 6 \mathrm{H}_{2} \mathrm{O}$ in aqueous solution under the atmospheric pressure and rehydration of their thermal decomposition products, Gypsum \& Lime, 1987 (1987) 88-98. DOI: 10.11451/ mukimate1953.1987.88

林 克郎, “ハイドロガーネット前駆体の液 相合成と C12A7 エレクトライドの作製”, 第 55 回セラミックス基礎科学討論会, 2017 年 1 月 (口頭発表).

3. 稲田幹, 守谷 静香, 榎本 尚也, 林 克郎, “八 イドロガーネット前駆体を経由したアニオ ン包接結晶 C12A7 の開発”, 2017 年度セラ ミックス総合研究会, 2017 年 9 月 (口頭発表). 